\title{
Using Online Video Lectures to Enrich Traditional Face-to-Face Courses
}

\author{
Suzanne C. Makarem \\ Asst. Prof., Virginia Commonwealth University, 301 W. Main Street, Richmond, VA \\ 23284, U.S.A. scmakarem@vcu.edu
}

(1)

\begin{abstract}
University educators need to meet changing needs of the digital generation by integrating technology through online content delivery. Despite the many advantages of online education, a large number of university professors are reluctant to make the transition from traditional-face-to-face lectures to online delivery, mainly due to the time, cost, and technical competence requirements to make this transition, in addition to the lack of beliefs in the legitimacy of online education. This article demonstrates the use of online video lectures to adapt traditional university courses to a blended format. The study is implemented for a School of Business Marketing course. We illustrate a cost-effective and timeefficient way for faculty members to record and share online video lectures with limited training and technical support. Using a student sample from two sections of the same marketing course, the study findings support the use of online video lectures as an effective way to free class time for learner-centred activities, without sacrificing student performance outcomes or course satisfaction.
\end{abstract}

Key Words: online instruction, blended course format, development of online videos for instruction, student attitudes, online video lectures

\section{INTRODUCTION}

The changing needs of millennial students require instructors to evolve through expanding the scope of traditional face-to-face courses with online content, such as video lectures in a blended course format (Keith \& Simmers, 2013). Offering some course content online using video lectures allows higher education instructors to dedicate more in-class time for learner-centered activities, such as integrating course concepts with examples, applying the material, inviting guest speakers, and developing student communication skills (Priluck, 2004). Consequently, instructors can cover more material without affecting student performance or taking away from personal student interaction with faculty (Mason et al., 2013). Past research has provided support for using the blended course format, also termed the flipped classroom successfully in university business courses (Garver \& Roberts, 2013; Thoms, 2012), and also in catering to students with special needs, such as deaf or hard-of-hearing students (Thoms, 2012). There is still however a need for pedagogical resources that outline the implementation of a blended course format in a way that is easy to adopt by university

DOI: $10.12973 / \mathrm{iji} .2015 .8212 \mathrm{a}$ 
instructors, especially those who are reluctant to move away from traditional face-toface teaching.

\section{LITERATURE REVIEW}

Online instructional tools are currently in wide adoption with one third of business schools offering online programs (Estelami, 2012). These programs have become a necessity in today's educational environment catering to the digital generation (Bistrow et al., 2011; Steiner \& Hyman, 2010). In the face of escalating costs and stagnant or shrinking budgets for state-supported institutions that are the primary vehicles for delivery of higher education in the United States, these online programs seem to be here to stay. Despite the many advantages of online courses including interactivity, flexibility, and students learning at their own pace, many students and faculty members prefer traditional courses (Priluck, 2004). A large number of professors do not believe in the legitimacy of online education; and many students do not appreciate the selflearning required by online courses (Comer \& Lenaghan, 2013).

From a student perspective, online education has disadvantages for students who prefer the classroom experience (Steiner \& Hyman, 2010). It has been associated with higher drop-out rates, student inability to learn on their own, student frustration with the lack of direct professor contact (Priluck, 2004), and information overload (Fortune et al., 2006). From faculty and administration perspective, online education has high cost requirements (Estelami, 2012), needs technical competence and training, and might involve substantial investment in facilities that are equipped with recording systems for real time course recording on-campus (Priluck, 2004). Online courses also rely heavily on faculty and staff with high level of comfort with technology (Estelami, 2012) and they can be very time-consuming. In fact, creating an online version of a course could take around 500 hours in development and technology support (Steiner \& Hyman, 2010), with 15-minute videos requiring more than 2 hours of recording and editing (Mason et al., 2012).

Because of these limitations, many researchers have recommended using a combination of online and face-to-face education in order to cater to different student needs and benefit from the advantages of both formats (Estelami, 2012; Ross \& Rosenbloom, 2011). One emerging trend in education is such blended or hybrid courses, which can vary by offering between 30 and 80 percent of their content online (Estelami, 2012). A blended course format, such as the flipped classroom, offers students the opportunity to learn content by watching online podcasts, then to meet the instructor face-to-face in an interactive classroom environment with limited lecturing (Thoms, 2012). Most past research has focused on investigating the effectiveness of web-based learning (Erdogan et al., 2008) or on comparing online and traditional face-to-face courses, while finding no significant differences in student performance outcomes (Fortune et al., 2006; Hansen, 2008; Priluck, 2004; Steiner \& Hyman, 2010).

This article contributes to past research on the implementation and effectiveness of blended courses in higher education, and more specifically in business education (Estelami, 2012), by illustrating the use of online video lectures as way for faculty 
members to adapt traditional face-to-face courses to a blended format, in order to accommodate the learning needs of different students while engaging in an innovative teaching activity. We describe the use of video recording software that allows instructors to record their lectures with limited cost, time, and technology requirements and without the need for technical assistance or equipped classrooms. We provide support for the effectiveness of this blended format by comparing student performance on exams and measuring student attitudes towards online video lectures.

\section{CONTEXT AND IMPLEMENTATION}

\section{Implementing the Blended Course Format}

To implement online video lectures as a way to enhance traditional face-to-face university courses, we used two sections of a marketing course on Buyer Behavior, taught at the business school of a south-eastern university. Buyer Behavior is an undergraduate, upper-level marketing course required for all marketing majors. The main objectives of the course are to provide an understanding of consumer behavior theories, and to apply consumer behavior concepts to better understand what customers do, and use this knowledge to make better company and consumer decisions.

Both sections were taught by the same instructor using the same syllabus, and met once a week. The first section was used for control as a traditional face-to-face course consisting of lectures during class time, in-class activities and discussions, student presentations, group work on the class project, and exams. In the second section, the instructor recorded 40-minute video lectures for 30 percent of the course chapters and posted them online using Blackboard (similar university platforms such as WebCT can be used). Out of 14 chapters covered in the course, 4 chapters were video recorded. These chapters included information on consumer personality and the self, consumer psychographics and lifestyles, consumer persuasion and communication, and organizational buying behavior. All the other activities during class-time were similar to the first section, except for the additional free time allowed by not having to go over the whole lecture for those lectures posted online.

The free time was used to host two guest speakers from local companies, to provide students with additional time to work on their group project, and to discuss interactively the course concepts covered in online video lectures. The two guest speakers covered topics related to two online video lectures; the first guest speaker was an account director at a national advertising firm and she talked about designing effective advertising campaigns, while the second guest speaker was a purchasing department director at a local organization and she talked about her organization's buying behavior. In-class discussions of online video lectures were dynamic in that they allowed students to raise and provide answers to thought-provoking questions about the lectures' content. Overall, these discussions reflected students' positive attitudes towards the online video lectures.

\section{Recording Online Video Lectures}

The main limitations of developing online video lectures are time commitment, cost, and technical competence required for faculty and staff. At many universities, video lectures 
are recorded on-campus in classrooms equipped with video recording technology or in faculty members' offices using technology that involves high initial competence training and technical support. Furthermore, online lectures usually consist of videos that show the instructor reading or presenting the material side-by-side to power point slides that the instructor goes through. Many instructors are however uncomfortable being on camera and taking the role of an actor delivering the material in a way that goes beyond just reading a script in order to engage students (Calk et al., 2007). Instructors teaching traditional face-to-face courses with no experience in online education can also be hesitant to embrace online learning, especially when their technology comfort is low (Bostrow et al., 2011; Priluck, 2004). To implement the blended course format, this study illustrates how to record online video lectures in a way that overcomes many of these limitations.

For the second section of Buyer Behavior, the instructor used Camtasia Studio Version 8 , a video recoding and editing software that can be downloaded to any university or personal computer with limited system requirements for the low costs of USD 125 per license, with a free trial available for 30 days. The instructor in this study used the laptop embedded microphone successfully with Camtasia and did not require any additional hardware. The software itself has a user-friendly interface that allows instructors to record anything they see on their computer screen by clicking as little as two buttons. The instructor using the software in this study invested minimal initial learning time of 60 minutes before starting to record a lecture. The task of recording online video lectures can be done at any location (e.g. instructor's office or home) with limited background noise. It requires the instructor to open an application such as a power point presentation and recording, without appearing on camera, what he or she wants the students to see on their screen. The powerful screen recording technology allows instructors to audio record their voice lectures while controlling what appears on screen including power point presentations, video aids they like to share with students, and any other online or offline content. By having these advantages, Camtasia enables professors to convert their offices or home offices into an adequate enough recording studio so that the hassles of scheduling and going through a centralized campus recording studios for every recording session are completely avoided.

In addition to the time required preparing for the lecture before recording, similar to traditional face-to-face courses, the instructor spent the same time recording the video that it would have taken him or her to present the lecture in class without student interaction. The online video lectures were limited to 40 minutes in order to echo the time students would spend in a 50-minutes traditional class session. Based on the past experience of the instructor in this study, during longer class sessions (75-minutes and 150-minutes), the instructor would not lecture for more than 40 minutes without engaging students in class activities or giving them a short break. Also, the instructor purposefully chose chapters with more straightforward material that do not usually elicit many student questions, based on past experience. After recording the videos, Camtasia allowed the instructor to export them in multiple format including mp4 video files that do not exceed 300 megabytes in size and which can be then uploaded to Blackboard or similar university platform in less than three minutes. Students were then able to 
download these files in less than three minutes and watch those using applications such as QuickTime Player, which can be downloaded for free on PC or Mac computers. Camtasia also allows instructors to export MOV videos to YouTube if they have a course channel. This process is straightforward and does not require more than five to ten minutes for every video lecture.

One advantage of using Blackboard or a similar university platform is that instructors are able to monitor not only the number of video downloads but also the specific students who downloaded the videos versus those who did not. The total time required to record and upload the online video lectures to Blackboard was about one hour on average, which is significantly shorter than the two hours required for recording a 15 minute video reported in past research (Mason et al., 2012). Additionally, instructors can use videos recorded once for a number of years, which makes the minimal investment in time much worth it.

The resulting videos in mp4 format showed a sequence of power point slides and embedded video and article content with a synchronized audio recording of the faculty's lecture. The lecture itself was not scripted but instead reflected the natural flow of a traditional face-to-face lecture with the instructor's lecturing style for the material that $\mathrm{s} / \mathrm{he}$ has prepared. It is important to note that the students watching the videos only heard the professor's voice while watching the recorded professor's computer screen and that there was no video of the professor. This provides an advantage over existing recording software used at many universities and which might cause faculty discomfort related to appearing on camera (Calk et al., 2007).

\section{METHOD}

\section{Research Design and Participants}

To demonstrate the effectiveness of using online video lectures, the instructor compared student performance on exams in both sections. The sample consisted of 86 undergraduate upper-level (juniors or seniors) marketing students (Traditional Section 1 $\mathrm{n}=38$, Blended Section $2 \mathrm{n}=48$ ). The same twenty multiple-choice questions spread over two exams were used in both sections, to test student knowledge of the material covered using online video lectures in Section 2 versus traditional class lectures in Section 1 .

Then, to understand student attitudes towards online video lectures a survey was used, at the end of the semester, to measure students' satisfaction levels with different aspects of the Buyer Behavior course in both sections. Students were asked to rate their overall satisfaction with the course and their satisfaction with different aspects of the course including class lecture content, pace, power points, and in-class activities. Additionally, students in the blended section 2 were asked to rate their satisfaction with online video lectures and to provide open-ended thoughts regarding the use of these lectures. All satisfaction ratings were measured on a 5-point scale from 1 , very dissatisfied to 5 , very satisfied (See Appendix).

\section{Data Analysis}


In order to compare performance outcomes and student attitudes towards different aspects of the course between the two sections, multiple independent samples t-tests were conducted, in addition to a qualitative content analysis for open-ended questions. The significance level of 0.05 was accepted for all statistical analyses.

\section{RESULTS AND DISCUSSION}

\section{Student Performance Outcomes}

A t-test was used to compare the mean percentages of students who correctly answered the twenty multiple-choice questions in both Buyer Behavior sections and it showed no significant differences, $\mathrm{m}_{1}$ (traditional section) $=77.7 \%$ and $\mathrm{m}_{2}$ (blended section) $=$ $76.5 \%$ (t-statistic $=0.771, p=0.45$ ). Consistent with previous research, there were no significant differences in student performance outcomes for online versus traditional course lectures. Erdogan et al. (2008) notes that although web-based instruction might not be an alternative to traditional face-to-face teaching, it is an efficient medium that allows for achieving similar performance outcomes, especially if enough support is provided to students. The results from this study support the appropriateness of using online video lectures for instructors who wish to offer course content in multiple formats, in a blended course environment, to cater to different student needs without drawbacks to student learning or performance.

\section{Student Attitudes towards Online Video Lectures}

When evaluating different teaching and learning tools, it is important to consider students' learning expectations and attitudes towards the medium used (Erdogan et al., 2008). A content analysis of student open-ended thoughts about online video lectures showed that $68 \%$ of students have positive attitudes towards this lecture format. In fact, they listed that online video lectures provide a good change in pace from regular lectures, help increase in-class interaction and activities, allow them to go on at their own pace, and are very helpful when studying for exams because they can listen to the lecture multiple times at any moment. Consistent with past research findings, it was evident that some students prefer to learn in class. In fact, $32 \%$ of students in the blended section indicated this preference. They specified in their comments that online video lectures create more work for them, that they do not want to teach themselves, that they focus better and retain more in class, and that they need face-to-face lectures in case they have questions.

Looking at student satisfaction ratings with online video lectures in the blended course format, it was evident that students had a positive attitude towards these lectures overall $(m=4.62)$, with $91.1 \%$ of the students indicating that they were satisfied or very satisfied (rating of 4 or 5). A positive student attitude is essential to achieve the benefits of any web-based education tool (Edogan et al., 2008). Additionally, a comparison of overall course satisfaction ratings and satisfaction levels with different course aspects, for the two sections of Buyer Behavior, showed no significant differences. Table 1 provides mean satisfaction ratings for all measures in both sections with t-test results comparing these means in the traditional face-to-face format versus the blended format. 
Table1: Student Satisfaction Ratings with Course Aspects

\begin{tabular}{lcccc} 
5-Point Satisfaction Rating for Scale Item & $\begin{array}{c}\text { Traditional } \\
\text { Section 1 } \\
\text { Mean } \\
N=38\end{array}$ & $\begin{array}{c}\text { Blended } \\
\text { Section } 2 \\
\text { Mean } \\
N=48\end{array}$ & $\begin{array}{c}\text { T-test of } \\
\text { Mean } \\
\text { Differences }\end{array}$ & $\begin{array}{c}p \text { - } \\
\text { value }\end{array}$ \\
\hline Class lecture content and clarity of explanation & 4.61 & 4.65 & .282 & .779 \\
\hline Class lecture pace and amount of information & 4.19 & 4.19 & -.028 & .978 \\
\hline $\begin{array}{l}\text { Lecture power point slides posted on } \\
\text { Blackboard }\end{array}$ & 4.69 & 4.83 & 1.209 & .231 \\
\hline Course articles and examples discussed in class & 4.60 & 4.49 & -.675 & .502 \\
\hline Other in-class activities & 4.33 & 4.22 & -.634 & .528 \\
\hline Online video lectures & N/A & 4.62 & N/A & N/A \\
\hline Overall Course Satisfaction & 4.36 & 4.41 & .317 & .752 \\
\hline
\end{tabular}

\section{CONCLUSION}

\section{Challenges and Concerns When Implementing Online Video Lectures}

When implementing online video lectures as a way to create a blended course in order to cater to students' various needs, one has to consider the implications for faculty and students. The main challenge is the need for faculty members to embrace online learning tools for a successful implementation. Despite the limited costs, time investment, and technical competence required to record online video lectures and share them with students using Camtasia, faculty members still need to believe in the value of online learning and to be willing and able to use this technology. Also, business or other schools need to provide the support and incentives necessary to encourage faculty members to engage in such teaching innovations.

Apart from time and cost investments required by learning and using Camtasia for his or her course, one obstacle faced by the instructor in this study is the inability to control and evaluate whether the students watched the video and if so, whether they were paying adequate attention throughout the whole online lecture. One way to handle this drawback is to give students assignments related to the content of video lectures. One example that could incentivize student engagement in online learning, without burdening faculty members with additional preparation time for assignment design and grading, is in-class pop-quizzes that allow students to receive extra credit grades based on their performance.

Another challenge is explaining the value of online learning to students. Our results are consistent with past studies in that about one third of the students have negative attitudes towards online learning (Birstrow et al., 2011). Faculty members need to address these students' concerns during face-to-face class meetings through in-class discussions of online video lectures content and through careful planning of learner-centered activities that clarify to students the value of freed-up class time resulting from online learning and the advantages of the blended course format. Students would be able to appreciate and engage in online learning, when they embrace it as a tool that allows them more inclass discussions with their professors, additional time for interacting with their peers, 
and the opportunities for real business applications through for example industry guest speakers. However, planning and scheduling such activities, made possible by class lecture time released due to online video lectures, can be quite challenging.

\section{Adaptability for Other Business and Higher Education Courses}

Although the online video lectures were implemented in one marketing course: Buyer Behavior, this innovation can be adapted to many marketing, business, and other university courses. Buyer Behavior was selected for this study because of the conceptual and theoretical aspects of a major part of the course content. Courses that heavily focus on hands-on student learning such as Marketing Research and Experiential Marketing might limit the effectiveness of online video lectures. However, most courses have a conceptual theoretical aspect and an application aspect. Online video lectures allow faculty members to cover conceptual material that they deem appropriate in an online learning setting. This will allow them to dedicate more in-class time for application tasks such as exercises, discussions, real world examples, and case studies.

Our findings indicate that student performance outcomes and course satisfaction ratings are not negatively affected by online learning. Additionally, the majority of students have a positive attitude towards online video lectures, which provide them with more flexibility to go over the material at their own pace, anytime, and multiple times. The blended course format provides students with the combined advantages of online learning flexibility and traditional face-to-face personal interactions with faculty, without jeopardizing the quality of the course. Internet technologies allow course content to be delivered in many ways. Online video lectures can be used as a tool for innovation in the teaching and learning process, in order to allow for more in-class interactions and application tasks.

\section{REFERENCES}

Bistrow, D.C. et al., (2011). To Be of not to Be: That Isn't the Question! An Empirical Look at Online Versus Traditional Brick-and-Mortar Courses at the University Level. Marketing Education Review, 21(3): 241-250.

Calk, R. et al., (2007). The Effective Delivery of a Streaming Video Course Lecture. Accounting Education: An International Journal, 16(1): 81-93.

Comer, D.R. \& Lenaghan J.A. (2013). Enhancing Discussions in the Asynchronous Online Classroom: The Lack of Face-to-Face Interaction Does not Lessen the Lesson. Journal of Management Education, 37: 261-294.

Erdogan, Y. et al., (2008). Factors that Influence Academic Achievement and Attitudes in Web-Based Education. International Journal of Instruction, 1: 31-47.

Estelami, H. (2012). An Exploratory Study of the Drivers of Student Satisfaction and Learning Experience in Hybrid-Online and Purely Online Marketing Courses. Marketing Education Review, 22: 143-155.

Fortune, M.F. et al., (2006). A Comparison of Online (high tech) and Traditional (high touch) Learning in Business Communication Courses in Silicon Valley. Journal of Education for Business, 81: 210-214. 
Garver, M.S. \& Roberts, B.A. (2013). Flippin g \& Clicking your Way to Higher-Order Learning. Marketing Education Review, 23: 17-21.

Hansen, D.E. (2008). Knowledge Transfer in Online Learning Environments. Journal of Marketing Education, 30: 93-105.

Keith, N. \& Simmers, C.S. (2013). Adapting the Marketing Educational Environment for Multi-Cultural Millennials: The Chinese Experience. Academy of Educational Leadership Journal, 17: 83-92.

Mason, G.S. et al., (2013). Comparing the Effectiveness of an Inverted Classroom to a Traditional Classroom in an Upper-Division Engineering Course. IEEE Transactions on Education, 56: 430-435.

Priluck, R. (2004). Web-Assisted Courses for Business Education: An Examination of Two Sections of Principles of Marketing. Journal of Marketing Education, 26: 161-173.

Ross, D.N. \& Rosenbloom, A. (2011). Reflections on Building and Teaching an Undergraduate Strategic Management Course in a Blended Format. Journal of Management Education, 35: 351-376.

Steiner, S.D. \& Hyman, M.R. (2010). Improving the Student Experience: Allowing Students Enrolled in a Required Course to Select Online or Face-to-Face Instruction. Marketing Education Review, 20: 29-33.

Thoms, C.L.V. (2012). Enhancing the Blended Learning Curriculum by Using the 'Flipped Classroom' Approach to Produce a Dynamic Learning Environment. Proceedings of ICERI2012 Conference, Madrid, Spain, 2150-2156.

\section{APPENDIX}

Survey: Students' Attitudes towards Online Video Lectures

Q1. Please rate your satisfaction level with the following aspects of MKTG 315 on a scale of 1 to 5 (1 being Very Dissatisfied and 5 being Very Satisfied):

\begin{tabular}{lccccc}
\hline & $\begin{array}{c}\text { Very } \\
\text { Dissatisfied }\end{array}$ & Neutral & $\begin{array}{c}\text { Very } \\
\text { Satisfied }\end{array}$ \\
\hline Class lecture content and clarity of explanation & 1 & 2 & 3 & 4 & 5 \\
\hline Class lecture pace and amount of information & 1 & 2 & 3 & 4 & 5 \\
\hline Lecture power point slides posted on Blackboard & 1 & 2 & 3 & 4 & 5 \\
\hline Course articles and examples discussed in class & 1 & 2 & 3 & 4 & 5 \\
\hline Other in-class activities & 1 & 2 & 3 & 4 & 5 \\
\hline Online video lectures & 1 & 2 & 3 & 4 & 5 \\
\hline Overall Course Satisfaction & 1 & 2 & 3 & 4 & 5 \\
\hline Class lecture content and clarity of explanation & 1 & 2 & 3 & 4 & 5 \\
\hline Q2. How wide
\end{tabular}

Q2. How would you feel about the use of more video online lectures to be watched outside of the classroom in order to have more room for in-class activities or guest speakers during class?

\section{Turkish Abstract}

Geleneksel Yüz-Yüze Dersleri Zenginleştirmede Online Video Dersleri Kullanma

Üniversite öğretim üyeleri dijital jenerasyonun değişen ihtiyaçlarını karşılamak için online 
içeriklerle teknolojiyi entegre etmeye ihtiyaç duymaktadır. Online eğitimin birçok avantajının yanı sıra zaman, maddi gider, teknik yeterlik gibi konuların yanında online eğitimin geçerliği olan zayıf inanç gibi konular yüzünden öğretim üyelerinin büyük bir çoğunluğu geleneksel yüz yüze eğitimden geçiş için isteksiz davranmaktadırlar. Bu makale geleneksel dersleri online video derslerle nasıl karma bir formata dönüştürüleceğini göstermektedir. Çalışma İşletme-Pazarlama Fakültesinde bir derste uygulanmıştır. Çalışmada sınırlı teknik eğitim ve destekle online video kaydetme ve paylaşmanın zaman ve maddi imkan tasarruflu bir yolunu göstermektedir. Pazarlama dersinden iki öğrenci örneklem grubuyla yapılan çalışmada bulgular online video derslerin kullanımının öğrenci merkezli etkinlikler yapmak için derslerde herhangi bir eksiklik yapmadan boş vakit oluşturmada etkili olduğunu göstermiştir.

Anahtar Kelimeler: online öğretim, karma ders formatı, online videoların öğretim için geliştirilmesi, öğrenci tutumu, online video dersleri

\section{French Abstract}

\section{L'Utilisation de Cours Vidéo En ligne pour Enrichir Cours Face à face Traditionnels}

Des éducateurs universitaires doivent respecter les besoins changeants de la génération numérique en intégrant la technologie par la livraison contente en ligne. Malgré les nombreux avantages d'enseignement en ligne, un grand nombre de professeurs d'université est réticent pour faire la transition de cours traditionnels-face-à-face à la livraison en ligne, principalement en raison du temps, le coût et des exigences de compétence techniques faire cette transition, en plus du manque de croyances en légitimité d'enseignement (éducation) en ligne. Cet article démontre l'utilisation de cours vidéo en ligne pour adapter des cours universitaires traditionnels à un format mélangé. L'étude est mise en œuvre pour une École d'Affaire le cours Marketing. Nous illustrons une façon rentable et permettant de gagner du temps pour des membres de faculté pour enregistrer et partager des cours vidéo en ligne avec la formation limitée et l'assistance technique. En utilisant un échantillon d'étudiant de deux sections du même cours marketing, les découvertes d'étude supportent l'utilisation de cours vidéo en ligne comme une façon effective de libérer le temps de classe pour des activités centrées sur l'apprenant, sans sacrifier des résultats de performance d'étudiant ou la satisfaction de cours.

Mots Clés: instruction en ligne, format de cours mélangé, développement de vidéos en ligne pour instruction, attitudes d'étudiant, cours vidéo en ligne

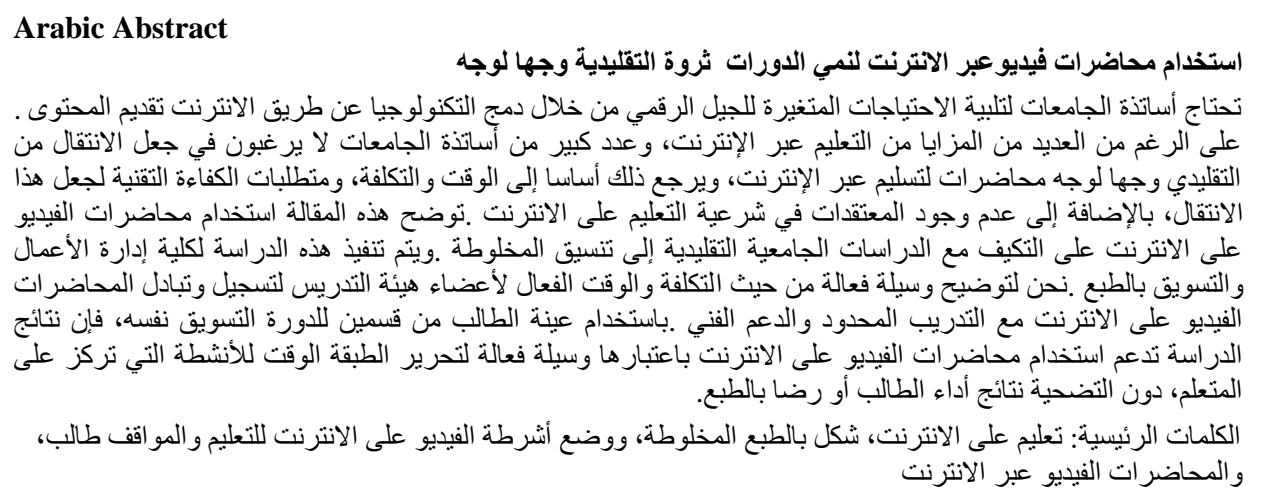

